\title{
Dairy intensification: Drivers, impacts and alternatives
}

\author{
Nathan Clay, Tara Garnett, Jamie Lorimer
}

Received: 16 July 2018/Revised: 13 February 2019/Accepted: 22 March 2019/Published online: 4 May 2019

\begin{abstract}
Dairy production systems have rapidly intensified over the past several decades. Dairy farms in many world regions are larger and concentrated in fewer hands. Higher productivity can increase overall economic gains but also incurs site-specific social and environmental costs. In this paper, we review the drivers and impacts of dairy intensification. We identify in the literature four prominent concerns about dairy intensification: the environment, animal welfare, socioeconomic well-being, and human health. We then critically assess three frameworks-sustainable intensification, multifunctionality, and agroecology—which promise win-win solutions to these concerns. We call for research and policy approaches that can better account for synergies and trade-offs among the multiple dimensions of dairy impacts. Specifically, we suggest the need to (1) consider dairy system transitions within broader processes of social-environmental change and (2) investigate how certain framings and metrics may lead to uneven socialenvironmental outcomes. Such work can help visualize transformations towards more equitable, ethical, and sustainable food systems.
\end{abstract}

Keywords Agricultural intensification - Agroecology · Food system - Multifunctional agriculture - Organic . Sustainable intensification

\section{INTRODUCTION}

Dairy farming has rapidly intensified over the past 50 years (FAO 2018a). Trends towards fewer larger farms have accelerated further in the past few decades as dairy producers struggle to compete in the burgeoning global marketplace for milk and dairy products (Freidberg 2009). Dairy intensification has complex and uneven effects on human-environment systems. Growing recognition of the negative impacts on the environment, animal welfare, equitable rural development, and human health has led to efforts to envision more sustainable and just dairy systems (Jay 2006). This paper speaks to an emerging literature on dairy intensification, considering drivers, impacts, and alternatives. It focuses on major temperate dairy producing regions of the European Union (EU), North America (NA), and Australia and New Zealand (ANZ).

Since the Second World War, dairy intensificationincreased milk output relative to inputs of feed, labour, land, or herd size-has been the dominant trajectory of dairy system change (Jay and Morad 2007). This productivist mindset-where increasing efficiency to enhance revenue from agricultural products is the primary objective-continues to inform dairy system policies in the EU, NA, and ANZ (Blayney 2002; McGregor and Houston 2017). If trends continue, global production of dairy products is expected to rise by $22 \%$ over the next decade, with dairy intensification likely to accelerate worldwide (FAO 2018a). Moreover, in many parts of the EU, NA, and ANZ, costs of milk production have risen while market price has dropped due to overproduction and retailer control of supply chains (MacDonald et al. 2016). A result of this is that thousands of farms go out of business every year (USDA 2018).

Current modes of dairy intensification are widely recognized to generate negative impacts along multiple dimensions: the environment (Del Prado et al. 2013), animal welfare (Koeck et al. 2014), human health (Westhoek et al. 2014), and rural livelihoods and well-being (Flaten 2002). In reviewing the literature, we find that research on the effects of dairy system intensification tends to consider just one or two of these dimensions. This can obscure understanding of the combined effects across these 
dimensions. Existing assessments of the impacts of dairy intensification tend to sit within disciplinary silos. In addition, this research tends to present static assessments of dairy systems rather than unpacking processes of humanenvironment change over time. This prevalence of monodimensional studies could wrongly indicate to policymakers that targeting a single set of goals can be enough to address the complex issues of dairy intensification. This in turn risks reinforcing an already single-issue approach to decision making in food system governance.

We suggest that it is essential to consider how the effects of dairy intensification can occur synergistically (e.g. livelihoods and environment can be simultaneously improved or worsened) or as trade-offs (e.g. enhanced economic efficiency may come at the expense of human health). Recent work has considered the political economic and ecological complexities surrounding rapid intensification in the meat industry (Emel and Neo 2015; Neo and Emel 2017). However, we find that similar work on dairy systems has been sparse. To work towards a more comprehensive understanding of dairy system transitions, this paper considers three solutions proposed by different sets of stakeholders for mitigating the negative impacts of intensified production systems: sustainable intensification, multifunctionality, and agroecology.

Sustainable intensification, in brief, denotes an aim of increasing productivity while simultaneously decreasing the negative environmental effects of conventional farming practices (Garnett et al. 2013). Agricultural multifunctionality refers to efforts to derive diverse benefits from agroecosystems that extend beyond production of food and fibre to include environmental services (e.g. carbon sequestration, biodiversity, and water quality) and maintenance of social-cultural processes (e.g. cultural landscapes and family farming units) (Wilson 2007). Agroecology emphasises the context-specific nature of agroecosystems and considers how ecological principles can help achieve goals of sustainability and social equity. We find that these frameworks have been inadequately applied to thinking about dairy system transitions. To initiate a dialogue on their potential value for policy and research, we consider to what degree these different framings help address the multiple human-environment dimensions of dairy intensification and how they may shape alternative trajectories for dairy systems.

This paper first documents the drivers of dairy system intensification and considers the human-environment impacts in four main areas of concern: the environment, animal welfare, human well-being, and human health. It then considers whether the framings of sustainable intensification, multifunctional agriculture, and agroecology are well positioned to address the multidimensional humanenvironment aspects of dairy systems and what sorts of system transformations these framings offer. We conclude by arguing for the need to (1) consider dairy landscapes within broader processes of socioecological change and (2) investigate how power imbalances can lead to uneven human-environment outcomes amid dairy system transitions.

\section{MAPPING DAIRY INTENSIFICATION}

\section{Intensification and concentration in dairy farming}

Agricultural intensification is rooted in a narrative of agricultural modernization, which defines progress in terms of increasing efficiency and productivity. In the EU, NA, and ANZ, the drive to enhance the economic efficiency of dairy production has guided dairy research and policy over the past 70 years (McGregor and Houston 2017). Policies such as the US Farm Bill and the EU's Common Agriculture Policy (CAP) have long incentivized dairy farm specialization and encouraged further scientific and technological innovations in agricultural engineering. This policy mandate of intensification centres on increasing the adoption of technologies (e.g. breeding and antibiotics) and use of inputs (e.g. commercially prepared feed) as well as substituting human labour with mechanized feeding and milking (Blayney 2002).

Dairy systems in the EU, NA, and ANZ intensified sharply following the Second World War (Freidberg 2009). While livestock farmers had traditionally produced both meat and dairy, specialized dairy farms became increasingly common. Shifts from pasture-based to confinement feeding systems (first in NA and later in the EU) further revolutionized the dairy industry by enabling consistent production year-round to support growing urban markets for milk (Dupuis 2002). These processes facilitated enormous gains in milk productivity at the level of individual cows, farms, and dairy production regions. As an example, the US dairy herd in 2001 produced three times as much milk as in 1950, even with $30 \%$ fewer cows (Blayney 2002). Annual yields per cow now commonly average more than 8000 litres across temperate regions (FAO 2018a).

Dairy system intensification comprises practices at farm-level, at regional levels, and at the level of individual animals. Farm specialization and mechanization strategies emphasize increasing milk production through larger herds, breeding technologies, indoor housing/feeding, energy and protein-dense commercial feeds, antibiotics and growth hormones (in NA), specialized staff or machines. Cows are artificially inseminated at a young age and milked for only a few years until productivity drops due to the steep declines in animal health caused by continuous pregnancy 
and lactation (Oltenacu and Broom 2010). In very intensive operations, cows are often kept indoors, sometimes yearround, with stall-feeding regimes of imported cereals and oilseed proteins to ensure steady milk production. Thus, intensive dairy operations rely heavily on external inputs: feed that is produced off farm and transported often long distances, water for animals and pasture irrigation, and milking and waste management infrastructure. Dairy production is concentrated regionally in areas with favourable political economic and ecological conditions (Blayney 2002). In major dairy areas, private or state-run companies and cooperatives (e.g. Muller-Wiseman in the UK, Fonterra in NZ) often emerge, putting up capital investment in technologies infrastructure (e.g. breeding, veterinary care, milk processing, and transportation) that further stimulate dairy intensification at a regional level (Jay and Morad 2007).

\section{Patterns and drivers of dairy intensification}

Intensification has occurred together with specialization, meaning fewer dairy farms and larger herd size per farm. In the USA, for example, there were around 640000 dairy farms in 1970 (Blayney 2002). By 2017 only about 40000 remained (USDA 2018). In the EU, NA, and ANZ, a clear majority of milk is now produced on relatively few larger farms. While the degree and timing of intensification and concentration vary substantially across and within dairy producing regions, a steep acceleration has occurred over the past two decades. In the USA, where intensification and concentration began relatively early, there was a sharp increase between 1997 (when half of all cows were in herds larger than 140) and 2012, by which time more than half of cows were in herds of more than 900 (MacDonald et al. 2016). Intensification has occurred more recently in the EU, with notable acceleration over the past 20 years. In the UK, for example, between 1995 and 2017 the number of dairy farms fell from around 35000 to 13000 while average herd size tripled (Dairy UK 2017). Intensification has been less extreme in NZ, where from 1990 to 2012 the number of farms decreased by $19 \%$ while average herd size increased by $147 \%$ (Statistics New Zealand 2012). 'Megadairies' housing 700 or more animals are only now appearing in the EU (FAO 2018a), while in the US West $90 \%$ of dairy farms had more than 500 cows in 2012 (MacDonald et al. 2016).

Transitions in dairy systems are influenced by structural factors such as government subsidies and regulations as well as by social, cultural, economic, and environmental processes. In 2010, cost of production per litre of milk was more than three times higher for farms with fewer than 50 cows than for farms with more than 2000 cows, a substantial gap that meant negative net returns for farms with fewer than 1000 cows (USDA 2010). The emphasis on economies of scale is further upheld by strong state support for industrial operations (Freidberg 2009). Dairy systems in the EU, NA, and ANZ operate through established 'industrial-commercial complexes' (Jay 2006): assemblages of infrastructure, technology, and education that facilitate commercial/industrial production and processing and that influence farm management decisions along productivist pathways.

Global markets and international trade agreements have further entrenched intensification as the dominant pathway of dairy system change. Recent pressures to compete in a global marketplace for commodity milk due to trade liberalization policies and skyrocketing dairy production in Brazil, India, and China have spurred deregulation and 'hyper-productivism' as dairy producers struggle to achieve efficiency (Dibden et al. 2009). Deregulation occurred decades ago in NZ and the USA and more recently in the EU with the removal of milk production quotas in 2015, a move that is expected to make it difficult for smaller farms to compete (Salou et al. 2017). Dairy supply chains are controlled by a few large processors Dairy Farmers of America in the US and Groupe Lactalis in France) who collect and pasteurise the milk and by supermarket chains (such as Walmart), which control a large majority of milk sales (Jay and Morad 2007). Indeed, by 2017 the 20 largest (by volume) milk processors controlled more than $25 \%$ of market share in worldwide milk production (IFCN 2018). Dairy farmers thus have little or no control over milk prices and, in the absence of adequate subsidies, have needed to intensify production or shift to higher value products such as organic, direct sales, or making cheese or yogurt.

\section{Nonlinear dynamics of dairy system change}

Approaching intensified agriculture as a binary production strategy can unproductively smooth the unevenness-between farms, regions, and various stakeholders in a sector-that emerges amid rapid agrarian change (Wilson 2008). Dairy intensification should be considered a complex process that unfolds in places over time. There is a need for studies exploring the socioecological struggles that emerge amid this complex and uneven change. For example, research could investigate how transitions towards intensive production as well as alternative production modes (such as organic) can eschew agro-industrial modes of production or, alternately, how they may recreate aspects of conventional production systems (cf. Guthman 2004).

Given the complex and political nature of dairy system transitions, research should consider how structural aspects (such as farm size, supply chains, and policies) can 
intersect with on-farm social and environmental contexts (Wilson and Burton 2015). While recent work has investigated the uneven human-environment outcomes surrounding transitions in meat production systems (Emel and Neo 2015; Neo and Emel 2017), similar research on dairy is notably lacking. In the next section, we aim to build the foundation for such work by reviewing the effects of dairy system intensification along four key dimensions highlighted in the literature.

\section{EFFECTS OF DAIRY INTENSIFICATION}

Research on dairy intensification has primarily considered its effects in four areas: (1) the environment; (2) animal welfare; (3) social and economic well-being; and (4) human health. Based on a review of the literature, we summarize and provide examples to illustrate the general findings and principal disciplinary associations of concerns arising in each of these areas.

\section{The environment}

The environmental impacts of dairy production can vary substantially depending on farm management practices (Poore and Nemecek 2018). The increased reliance of intensive dairy systems on inputs can exacerbate some negative environmental effects, both directly and indirectly, and alleviate others (Eshel et al. 2014). Commonly studied environmental impacts of dairy systems include emission of greenhouse gases (GHGs); soil and water pollution; biodiversity loss and wildlife health; nutrient cycles (primarily nitrogen and phosphorus); and land use change.

Dairy production gives rise to the emission of three GHGs: carbon dioxide $\left(\mathrm{CO}_{2}\right.$, via energy use and land use change), nitrous oxide $\left(\mathrm{N}_{2} \mathrm{O}\right.$, from feed production and excreta), and methane $\left(\mathrm{CH}_{4}\right.$, enteric and from manure). The process of intensification can increase some emissions while reducing others. As such, results are mixed as to how intensification broadly affects GHG emissions. Some studies suggest that more intensive and consolidated dairy production can decrease overall GHG emissions (Clark and Tilman 2017). On the other hand, some argue that compared to grazing-based systems (which may store and sequester carbon in grasslands in some contexts) more intensive dairy operations generate higher indirect carbon emissions because of their greater reliance on imported feed (O'Brien et al. 2014; Battini et al. 2016). Others, however, find that even when feed production is considered, intensive systems use less land overall, and as such are implicated in less land-use change related $\mathrm{CO}_{2}$ release, leading to lower overall emissions per unit of output (Gerssen-Gondelach et al. 2017).

Intensive dairy production leads to soil and water pollution. Synthetic fertilisers (especially nitrogen and phosphorus) are used to produce feed (generally maize, soy, and barley) and supplements (Cederberg and Mattsson, 2000; Foote et al. 2015). The increased use of fertilizers (organic and inorganic), use of water, and manure disposal issues of large farms can lead to high concentrations of nitrogen, phosphorous, and animal waste. If these are not adequately managed, they can pollute soil, river systems, and shallow aquifers, damaging ecosystems and decreasing the quality of freshwater (Scarsbrook and Melland 2015). While productivity increases mean that less land is needed per unit of milk produced, the pollution from that land increases (Gerssen-Gondelach et al. 2017).

Intensive dairy production impacts biodiversity and ecosystem health directly (through land use changes onfarm) and indirectly (through feed production processes and associated land conversion off-farm). Their reliance on monocultural pasture and high use of fertilizers mean that intensive dairy systems present risks to biodiversity and ecosystem stability in traditionally biodiverse grasslands (De Lucia et al. 2017). Grassland homogeneity can decrease species diversity and richness. For instance, studies in France show that avian populations are less diverse nearer to more intensified livestock production (Dross et al. 2017). Research in Italy similarly indicates decreased butterfly species richness with transitions to more intensive dairy systems (Jerrentrup et al. 2016). On the other hand, grazing-based dairy systems have an opportunity cost in that more land devoted to pasture means less overall land that could be set aside for nature conservation (Cederberg and Mattsson 2000).

\section{Animal welfare}

Discussions about animal welfare generally begin with an often-unarticulated ethical assumption that it is morally acceptable for humans to use animals so long as they ensure that animals are free of physical and mental stress and able to experience positive feelings (Buller and Morris 2003). By contrast, animal rights movements consider any use of animals to be morally objectionable and argue for the development of dairy and meat alternatives (Garner 2016). Understandings of animal welfare tend to include consideration of three aspects: (1) that welfare comprises animals' essential health and functioning (i.e. absence of disease and injury); (2) the need to consider animals' 'affective states' (such as pain, distress, and pleasure) and how positives and negatives add up to a quantitative indicator of well-being; and (3) animals' freedom to pursue 'natural' behaviours (e.g. grazing in open air), including 
their ability to exercise control in a given situation to remove themselves from 'poor' situations and place themselves in more positive mental and physical states (Fraser 2008; Ohl and Van der Staay 2012). In animal welfare regulations, definitions often combine elements of these positions, encouraging quantification of states of well-being experienced by animals in a mental as well as physical sense (Dawkins 2008). In practice, however, policymakers tend to emphasise absence of disease and injury, which is arguably simpler to measure.

It is possible to have high and low animal welfare in all production systems, including in those defined as extensive, organic or intensive. However, in very intensive confined feeding operations there are arguably limits to how 'good' welfare can be (Webster 1994). Rapid intensification in the dairy sector can have considerable impacts on animals' physical and mental well-being, particularly in high-income countries, where measures to improve productivity deliver only moderate gains, often at the expense of animal welfare (Haskell et al. 2006; LeBlanc et al. 2006). In intensive operations, cows often lack freedom to perform natural behaviours of grazing, reproducing, and socializing in pasture but instead live in housing regimes that constrain movement and that require animals to stand on concrete floors for extended periods of time (von Keyserlingk et al. 2009). Intensive dairy systems have been shown to have a higher prevalence of lameness and other disease (Koeck et al. 2014). Breeding cows for higher productivity also exacerbates physical and emotional stress on animals, thereby decreasing their welfare (Oltenacu and Broom 2010). Moreover, the lower levels of interaction between cows and stockmen that are common on intensive farms can increase the risk that animal welfare issues go unnoticed (Burton et al. 2012), although on the other hand larger farms may have greater access to specialised veterinary care. Management strategies that aim to optimize milk productivity can negatively impact animals' life cycles. For example, in intensive operations, cows are artificially inseminated again shortly after they have given birth to a calf, and then slaughtered after only a few pregnancy-lactation periods (von Keyserlingk and Weary 2017).

\section{Livelihoods and well-being}

The intensification of dairy farming has complex and uneven effects on various social, cultural, and economic dimensions of human well-being. Findings vary depending on the disciplinary framing and the scale of analysis. Economists tend to consider the monetary costs and benefits of various milk production regimes, often conducting national-level analyses of the structural factors influencing transitions and impacts in dairy systems (e.g. Zimmermann and Heckelei 2012). At the national level, there can be demonstrable economic benefits of increasing dairy farm productivity. For instance, in New Zealand dairy exports increased by $460 \%$ between 1990 and 2012 due to productivity increases from intensification, leading to gains in Gross Domestic Product (GDP) (Statistics New Zealand 2012). In identifying macro-level economic benefits of intensive systems, this work can generate support for policies that incentivize further dairy intensification (Mcgregor and Houston 2017).

On the other hand, sociologists, anthropologists, and geographers tend to consider broader socio-cultural and political economic issues surrounding intensification at more local levels, speaking to fundamental ideological debates concerning the role of agriculture in an increasingly urbanised world (Galt 2013). This work has investigated issues such as power asymmetries that are inherent in an industrial agricultural model, the loss of small scale farms due to price competition, the replacement of traditional skills and ways of life with a corporate mindset, and how trading regimes can undermine small scale production (Davidson 2002; Diamond 2013; Krieg 2014). Studies at local and regional levels demonstrate that the drive to increase output amid falling milk prices can push small and medium-size farms out of business if they are unable to restructure their enterprises (Davidson and Schwarzweller 1995; Krieg 2014). This can have cascading effects in that family farming becomes less viable, rural employment opportunities decrease, and cultural landscapes may disappear (Davidson 2002).

Such work generally finds that transitions to intensive dairy production systems can have uneven impacts in rural areas, leading to marginalization of some households across and within production regions. For example, Davidson and Schwarzweller (1995) demonstrate the nuances of marginalization and the vulnerable position of dairy producers in the Midwest US to rapid shifts in markets or policies. Another common finding of research on dairy system intensification is that the cost savings that are achieved in more intensive operations can in part be attributed to lower human labour input, which generally results in losses of employment for family and non-family dairy workers (Davidson 2002). As a case study from Norway demonstrates, these losses of rural employment opportunities have the greatest negative impacts on family members and communities in areas distant from urban centres where the bulk of milk is produced on small farms and where there are fewer non-farm livelihood options (Flaten 2002). Some have considered gendered impacts of dairy intensification on family farms, illustrating how intensification can validate men's roles as 'farmer-managers' while diminishing the value of women's contributions to farm household labour burdens (Alston et al. 
2017). Other recent work explores how marginalization occurs due to a confluence of biophysical and social factors. For example, Ricard (2015) demonstrates that in the absence of EU milk production quotas, greater competition and production gaps between highland and lowland areas have made it challenging for producers in mountainous areas to remain in business.

\section{Human health}

The links between dairy intensification and human health are complicated and contested. Health is more than the absence of disease and has long been defined as the ability to achieve states of physical, mental, and social well-being (WHO 1946). In shaping what people eat, the cultural, economic, political, and environmental dynamics of food systems have a major influence on population health: around 2 billion people have nutritional deficiencies and another 2 billion are overweight (WHO 2018). At the same time, the links between health and diet have become increasingly prevalent in scientific research and public policies (Springmann et al. 2016). Intensive dairy systems can present direct risks to human health through acute and chronic soil, air, and water pollution as well as by increasing exposure to zoonotic diseases, pathogens, and exacerbating risk of anti-microbial resistance (Wing and Wolf 2000). Dairy intensification can also have indirect impacts on human health, which from the level of the individual to populations are hotly contested. On the one hand, by reducing the cost of dairy products (which are important sources of protein and micronutrients), intensive dairy production may contribute to the nutritional adequacy of diets, a point long heralded in the US milk industry (Dupuis 2002) and in international development policies (FAO 2018a). On the other hand, the overabundance of low-cost dairy products may reduce dietary diversity and lead to increased cardiovascular disease (Alexander et al. 2016). However, other recent studies indicate weak or no relationship between milk, butter, and cheese consumption and cardiovascular disease, suggesting that dairy products contain amino acids, vitamins, minerals, and fats that may in fact provide a net health benefit (Dehghan et al. 2018).

While the links between dairy and health remain inconclusive, food systems continue to be marked by inequities in ability to access nutritious, healthy food (Allen 2008). Combined with high socioeconomic inequality and pre-existing health disparities, the lack of access to healthy food has led to higher rates of obesity, heart disease, cancer, and diabetes (Alkon and Mares 2012). Neoliberal agricultural policies have further concentrated power with agro-industry such that the current food regime is rife with health injustice: food insecurity, malnutrition, and diet-related health issues arise disproportionately among black, latino, and low-income communities (Guthman 2011). Given the complexities and the political nature of links between dairy intensification and human health, it is essential to consider the social, economic, and cultural contexts of dairy consumption and production and how they generate uneven health outcomes.

\section{Synergies and trade-offs across dimensions in dairy production-consumption}

Far less research has considered how these multiple dimensions (categorized in Fig. 1) of dairy intensification interact. This presents a critical limitation in understanding the synergies and trade-offs of current and future dairy systems. However, some recent work has considered how trade-offs and synergies can emerge. As an example of negative synergies between economic and environmental effects, research in Ireland indicates that intensified dairy operations using imported concentrate feed increase the carbon footprint of milk while decreasing farm profit margins due to only incremental increases in per-cow productivity (O'Brien et al. 2015). As an example of tradeoffs between economic benefits and health outcomes, research indicates that the predominant economic procedure of valuing agriculture in terms of GDP does not account for its environmental or health impacts, distorting market prices for food in ways that can lead to overproduction and overconsumption (Pretty et al. 2000; Tilman and Clark 2014). Other work suggests the potential for positive synergies between health and the environment, where curbing consumption of meat and dairy in the EU would likely improve environmental outcomes by reducing resources devoted to their production (Westhoek et al. 2014; Springmann et al. 2016).

Research has also considered how environmental and political economic contexts (including policy responses to environmental change) intersect to shape outcomes in dairy systems. For example, drought and concerns for water quality and river health have led to policies in Australia that restrict water usage on irrigated dairy farms, resulting in altered livelihood strategies and gender relations thattogether with the impacts of climate change-have reduced farm productivity (Alston et al. 2017). As an example of trade-offs between climate change mitigation policies and animal welfare, a recent study suggests that intensification is often promoted as a route to improving GHG efficiency of dairy; however, this can be at a cost to animal welfare (Shields and Orme-Evans 2015). Importantly, the benefits and trade-offs of food system adjustments are context specific, emerging at both regional and global levels (Springmann et al. 2016). This suggests the need for interdisciplinary research and policy on dairy systems that 


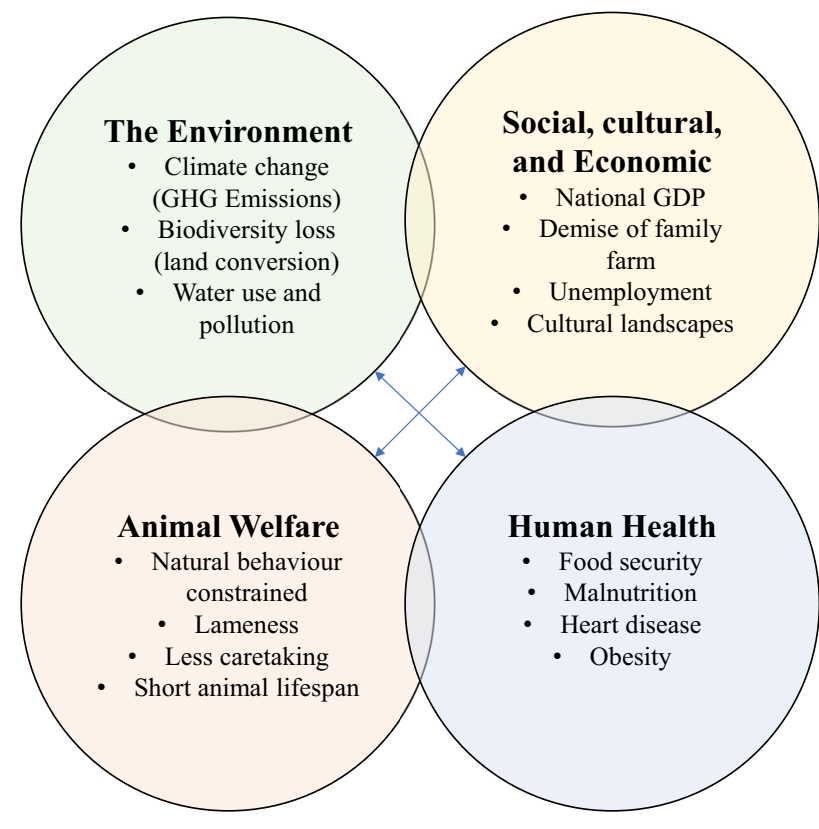

Fig. 1 The impacts of dairy intensification along four dimensions

can reconcile complex multi-scalar (that is, local to global) processes.

\section{FRAMING DAIRY TRANSITIONS}

Recognition of these negative impacts of intensification has led to efforts to envision and enact alternative dairy futures. These efforts can be categorized into three broad framings that shape research and ongoing policy and advocacy agendas on dairy production and consumption: (1) sustainable intensification, (2) multifunctional agriculture (including alternative food networks), and (3) agroecology. These framings are compared in Table 1. We consider the relative merits of each of these alternatives to conventional dairy systems. It is important to recognize that these framings are in flux. They are defined by various groups in different ways and are contested among those who employ them. Moreover, while these framings have been considered in some detail in work on agriculture at large, they have not featured substantially in research and policy on dairy systems. We begin to address this gap by considering how these framings broadly orientate dairy research and policy. For each framing, we (1) provide a general description, noting briefly if and how it has been employed in research and policy on dairy; (2) discuss how well the approach may be positioned to assess the multidimensional and interlinked environmental, animal welfare, socioeconomic, and human health related issues of dairy systems (as discussed above); and (3) consider how the framing envisions dairy futures and the degree of systemic change- from subtle tweaks to more radical transformation-contingent upon those futures. Having considered the relative merits and drawbacks of the three alternative framings, we then develop suggestions for future research and policy.

\section{Sustainable intensification}

One proposed strategy for mitigating the negative environmental impacts of conventionally intensive agriculture is sustainable intensification (SI). SI emerged as a response to the acknowledged need to increase food production to meet growing demand and the recognition that agricultural production can have negative environmental impacts (Pretty et al. 2011). To increase food production without impinging on resources and the environment, SI emphasizes the importance of increasing productivity per unit land (Godfray et al. 2010). SI has been employed worldwide. It features in agricultural policies of numerous countries and as an organizing concept of international organizations, yet it is defined in different ways by different groups (Godfray 2015). As applied in diversified farming systems of lower-income countries in Africa, for example, some maintain that SI can increase agricultural productivity through a combination of external technical knowledge and local agro-ecological knowledge (Pretty et al. 2011). In this sense, SI merges a productivist mindset with appreciation of biophysical and social variations in farming landscapes and emphasises the valuable role of small farm families and their local knowledge in achieving higher agricultural yields in socially and environmentally sustainable ways (Vanlauwe et al. 2014).

However, as applied in the global North, SI tends to be interpreted quite differently. While SI is a nascent concept in the dairy sector, it is often framed as a response to issues of inefficient production, where minimizing negative environmental impacts can enhance productivity (Soteriades et al. 2016). In turn, sustainability has tended to be conceptualized as something that can be achieved by enhancing the efficiency of existing operations through use of scientific and technological advances, with little attention paid to local agro-ecological knowledge and social-environmental variation. SI strategies in the dairy sector tend to target environmental issues that are also seen as economic inefficiencies (e.g. reducing GHG emissions by breeding cows to emit less methane or planting grasses that require less nitrogen fertilizer [Foresight 2011]). In practice, SI's arguably narrow framing of increasing production without increasing resource use or environmental impact makes it somewhat poorly positioned to address the multidimensional issues associated with dairy systems, particularly animal welfare, human health, and social elements. Although in theory SI diverges from conventional inputbased intensification in terms of the need to reduce 
Table 1 Comparing the relative merits of the three research/policy framings for alternative dairy systems

\begin{tabular}{|c|c|c|c|}
\hline & Sustainable intensification & Multifunctionality & Agroecology \\
\hline Premise & $\begin{array}{l}\text { Need to increase food production while } \\
\text { reducing resource use; characterized } \\
\text { by supply-side tweaks to enable lower } \\
\text { resource use that conserves } \\
\text { biodiversity and reduces GHG } \\
\text { emissions }\end{array}$ & $\begin{array}{l}\text { Rural landscapes more than food } \\
\text { production: also have cultural and } \\
\text { environmental value; characterized by } \\
\text { changes to production-consumption } \\
\text { networks that account for these values }\end{array}$ & $\begin{array}{l}\text { Self-sufficient production- } \\
\text { consumption systems (minimizing } \\
\text { external inputs) that optimize } \\
\text { local knowledge of biophysical } \\
\text { elements to enhance food } \\
\text { sovereignty and justice }\end{array}$ \\
\hline $\begin{array}{l}\text { What does the system } \\
\text { look like? }\end{array}$ & $\begin{array}{l}\text { Very large farms; investment in new } \\
\text { technologies to minimize resource use } \\
\text { (land, water, nutrients) and GHG } \\
\text { emissions and to better manage } \\
\text { nutrients to prevent water pollution; } \\
\text { common mechanisms include genetic } \\
\text { and other modification of animals and } \\
\text { feed as well as grazing management }\end{array}$ & $\begin{array}{l}\text { Organic or 'alternative food networks' } \\
\text { such as community supported } \\
\text { agriculture, which shorten supply } \\
\text { chains and add value, often through } \\
\text { substituting organic inputs; schemes } \\
\text { of payments for environmental } \\
\text { services such as planting trees; } \\
\text { productivity often lower than } \\
\text { conventional }\end{array}$ & $\begin{array}{l}\text { Diversified farming that includes } \\
\text { crops and livestock; ecologically } \\
\text { grounded techniques such as } \\
\text { conservation tillage, green } \\
\text { manure, biological pest control, } \\
\text { agroforestry, rainwater } \\
\text { harvesting; farmer empowerment } \\
\text { through learning and adaptive } \\
\text { decision making }\end{array}$ \\
\hline $\begin{array}{l}\text { Does it address } \\
\text { multiple human- } \\
\text { environment } \\
\text { dimensions of } \\
\text { dairy systems? }\end{array}$ & $\begin{array}{l}\text { Economic and some environmental } \\
\text { issues (e.g. GHG emissions); little } \\
\text { about health and social issues, or } \\
\text { animal welfare }\end{array}$ & $\begin{array}{l}\text { Social and economic; some } \\
\text { environmental aspects (e.g. ecosystem } \\
\text { services); little about animal welfare } \\
\text { or health }\end{array}$ & $\begin{array}{l}\text { Environmental, political, and social } \\
\text { less attention to health and anima } \\
\text { welfare }\end{array}$ \\
\hline $\begin{array}{l}\text { How feasible is it to } \\
\quad \text { implement as } \\
\text { policy? }\end{array}$ & $\begin{array}{l}\text { High feasibility due to technological } \\
\text { nature of changes and continued } \\
\text { productivist mindset }\end{array}$ & $\begin{array}{l}\text { Moderate feasibility due to simple } \\
\text { adjustments to production systems; } \\
\text { but inadequately defined }\end{array}$ & $\begin{array}{l}\text { Low feasibility due to challenges of } \\
\text { scaling up and mainstreaming in } \\
\text { policies that are structured around } \\
\text { industrial agriculture }\end{array}$ \\
\hline $\begin{array}{l}\text { What transformation } \\
\text { does it suggest or } \\
\text { require? }\end{array}$ & $\begin{array}{l}\text { Low level of food system } \\
\text { transformation, mostly relevant for } \\
\text { large farms; fixes mainly technical }\end{array}$ & $\begin{array}{l}\text { Moderate transformation needed; } \\
\text { Mostly relevant for small and medium } \\
\text { farms }\end{array}$ & $\begin{array}{l}\text { High level of transformation; mostly } \\
\text { relevant for small, mixed crop- } \\
\text { livestock systems }\end{array}$ \\
\hline $\begin{array}{l}\text { What change to } \\
\text { consumption does } \\
\text { it suggest or } \\
\text { require? }\end{array}$ & $\begin{array}{l}\text { Low change to amount of consumption; } \\
\text { designed to meet business as usual } \\
\text { predicted increased food demands of } \\
\text { growing consumption }\end{array}$ & $\begin{array}{l}\text { Moderate change: changing type of } \\
\text { consumption (e.g. more organic, } \\
\text { local, artisanal dairy), but little about } \\
\text { amount of dairy consumed }\end{array}$ & $\begin{array}{l}\text { Moderate change: need to reduce } \\
\text { consumption for this model to } \\
\text { work }\end{array}$ \\
\hline
\end{tabular}

consumption (Godfray 2015), in practice it is limited by its supply side emphasis on increasing agricultural efficiency through advances in technology and management (Tilman et al. 2011).

There is a recognized need to consider how to derive more holistic benefits from SI that go beyond increasing aggregate crop yields (Garnett et al. 2013). Some have expressed concern that SI has become merely another iteration of the 'sustainability' buzzword, more akin to greenwashing than to fundamental transformation of agricultural systems (Loos et al. 2014). Questions remain about how to balance trade-offs between sustainability and productivity and what is meant by environmental efficiency (Godfray 2015). With its techno-scientific approach and focus on environmental and economic issues, there may be limits to how far SI can be expanded to encompass multidimensional concerns such as livelihoods, animal welfare, and health. Perhaps the worst-case scenario would be that employing SI as a research and policy framing bolsters a narrow conceptualization of dairy transformation as a drive towards greater economic-efficiency. That could divert attention from the complex social-ecological processes that shape the multidimensional impacts of dairy production. It could also risk enabling the highest-impact dairy producers to continue relatively unchanged, while affording lowerimpact producers (i.e. less intensive operations) little opportunity to further reduce impacts. In these ways, SI could further entrench conventional production practices and contribute to pushing smaller farms out of business (Vanloqueren and Baret 2009). Nevertheless, components of sustainable intensification may prove valuable in addressing some of the negative impacts of dairy intensification, particularly if applied together with insights from other framings.

\section{Multifunctional agriculture}

A second framing is multifunctional agriculture, a nonproductivist paradigm wherein rural landscapes are valued for diverse services beyond agricultural production (Wilson and Burton 2015). As a policy platform, multifunctionality often reintegrates agriculture with rural development 
initiatives (e.g. reducing poverty and enhancing livelihoods) and merges these with agendas of environmental protection (Wilson 2007), thereby shifting from a sectoral focus on agriculture to a more holistic focus on regions (Marsden and Sonnino 2008). In theory, this regional focus enables policies to target human-environment components of multifunctional agricultural landscapes, such as helping rural landowners diversify their livelihoods, contribute to non-agricultural ecosystem services (e.g. biodiversity or climate change mitigation), and adopt mechanisms to generate further value from production such as by converting to organic production or developing closer and more direct linkages with consumers in order to capture a greater share of product value (Rache and Argent 2015). Multifunctional landscapes also emphasize the upkeep of social and cultural services, such as family farming and pastoral aesthetics of rural landscapes, which have value for rural communities and for agritourism (Freidberg 2009).

Multifunctional agriculture has often emerged organically amid intensification and concentration of dairy production. Smaller producers have remained in business by diversifying livelihoods (e.g. working in off-farm jobs) or by making changes to add value to existing production models (e.g. converting to organic or providing ecosystem services) (Davidson and Schwarzweller 1995; Krieg 2014). Although there is growing attention to alternative food networks and conversion to organic dairy production, little work has addressed multifunctionality in dairy systems specifically. In theory, the multifunctional agriculture framing considers multiple social and environmental dimensions. Likewise, in its aim to shift towards a broader conception of rural landscapes than merely places where food and fibre are produced, multifunctional agriculture appears to call for more fundamental transformations to production systems than does SI.

However, in practice multifunctional agriculture often takes the form of environmental and amenity schemes (such as CAP greening measures that pay farmers for planting hedgerows). Programs to enhance multifunctionality of agriculture have drawn criticism for hewing to predominantly economistic measures of success (such as quantifying biodiversity as an ecosystem service), thereby undervaluing more systemic regulating services such as climate and water quality (Garzon 2005). Such policies have arguably failed to offer genuine rural development opportunities for small farmers because they act more as subsidies and can constrict the overall state budget allotted to agriculture (Marsden and Sonnino 2008). Some suggest that multifunctional agriculture risks weakening state regulation by shifting accountability to market mechanisms (McCarthy 2005). Others have demonstrated that in some cases organic milk systems can follow the same path as conventional milk, trending towards domination by agribusiness dairies that employ large confined animal feeding operations (DuPuis 2002). By these accounts, multifunctional agriculture has fallen short of its transformative and multidimensional potential.

\section{Agroecology}

A third framing is agroecology, which came of age in 1930s North America and Europe and is variously defined as a scientific approach, a social movement, and a practice (Wezel and Soldat 2009). As a research approach fusing ecology and agronomy, agroecology has been defined as "the science of applying ecological concepts and principles to the design and management of sustainable food systems," (Gliessman 2007, p. 369). As a practice, agroecology developed through attention to local ecological knowledge and recognition of socioeconomic factors (Tomich et al. 2011). More broadly still, agroecology has been defined as "the integrative study of the ecology of the entire food system, encompassing ecological, economic and social dimensions" (Francis et al. 2003, p. 100). In considering the social, political, and cultural contexts in which farm management decisions are made, agroecologists often stress the importance of social and political change to enabling food system sustainability and justice (Vandermeer and Perfecto 2017). As such, agroecology is closely aligned with political and social movements such as La Via Campesina.

Agroecological principles of livestock keeping (e.g. mixed systems that combine livestock with trees and annual crops to enhance overall farm productivity) are widely practiced in low and middle-income countries. Although once common in the global North, similar agroecological practices have been challenging to implement in regions where large-scale intensive dairy production dominates (FAO 2018b). However, there is growing interest in agroecological approaches to dairy production in temperate regions (Bonaudo et al. 2014), where these approaches tend to emphasise the self-sufficiency of farms, particularly as regards animal feed (Lebacq et al. 2015). Other practices include permaculture systems, breeding more multifunctional livestock rather than raising breeds with the highest milk production, or incorporating semi-natural grasslands into mountain agriculture (Dumont et al. 2014).

Agroecology is closely aligned with multifunctional agriculture (Wibbelmann et al. 2013) and similarly aims to create opportunities for smaller producers who have been excluded from benefits of the industrializing dairy sector (FAO 2018b). But agroecology's practical and multidisciplinary origins set it apart from multifunctionality and SI in terms of its consideration of the multiple dimensions of dairy systems and its emphasis on the need to 
fundamentally transform food systems as part of a broader agenda of social change (Tomich et al. 2011). As both a scientific discipline and social movement, agroecology emphasises multidisciplinary studies on food systems that span social and natural sciences, close interactions with farmers, and practical engagement with activist groups aiming to catalyse social change (Vandermeer and Perfecto 2017). Of the three framings reviewed here, agroecology is arguably the best positioned to address the uneven power dynamics that underlie trends of dairy intensification (Jay and Morad 2007).

However, there are substantial challenges to mainstreaming agroecology in policy agendas and research programmes (Wibbelmann et al. 2013). The continued domination of productivist paradigms in discussions about livestock production have limited the research funding and agricultural extension activities exploring agroecological approaches (Vanloqueren and Baret 2009; McGregor and Houston 2017). Indeed, the emphasis on optimizing system productivity at the expense of the productivity of individual components (such as milk output) makes agroecology fundamentally at odds with productivist agricultural models that are predicated on specialisation (Dumont et al. 2014). This also has the effect that agroecological approaches to livestock production are challenging to implement at a large scale (Moraine et al. 2014; FAO 2018b). Thus, while agroecology may offer the most radical food system transformation of the three framings, such transformation is predicated on substantial political economic change.

\section{TOWARDS MULTIDIMENSIONAL RESEARCH AND DAIRY SYSTEM TRANSFORMATIONS}

Not only do these three framings of agricultural transitions elude clear definitions, they are also contested, they overlap conceptually, and in practice they are often found juxtaposed across rural landscapes. For example, in the EU, multiple production systems coexist in a patchwork at local and regional levels; conventional (non-intensive) operations often occur next to organic mixed systems, intensive grassland systems, and intensive maize silage systems (European Commission 2016). Transitions from conventional to multifunctional agriculture occur through heterogenous and nonlinear pathways (Wilson 2008). Likewise, there is substantial overlap between multifunctionality and agroecology, as evidenced by efforts to consider how agroecological principles could help in the design of multifunctional landscapes (Lovell et al. 2010). And agroecological principles can also be applied in SI (Tittonell 2014). Moreover, the decision of which framework to apply is inherently political, as it determines the criteria of research and policies and therefore shapes agrarian and food futures. It is further important to consider how findings and policies might differ depending on the level of analysis that is adopted (e.g. farm, or region, or nation). For example, national and international assessments tend to privilege SI. However, as this review has shown, the processes driving dairy intensification, the multiple dimensions of their impacts, and the policy responses span multiple levels of organization, making cross-scalar research essential.

As discussed in Sect. 3, work on the effects of dairy intensification has tended to isolate social or environmental dimensions. Occasionally, research and policy considers interactions of these dimensions, but generally with little depth, such as by highlighting links between GHG emissions and economic productivity, rather than pursuing more involved research that considers systemic social, political, and ecological processes. Yet, research and policy on environmental issues are often rooted in values, which structure understanding of how food system sustainability is or should be defined (Garnett 2014). For example, in studies rooted in a productivist agriculture ethic, environmental management tends to be circumscribed by a political economy that prioritizes economic competition in a global dairy market (Jay 2006). There is a need for policyrelevant research that is not beholden to pre-existing overly simple narratives (e.g. productivist or post-productivist), which obscure understanding of the complexities of dairy system change and its multidimensional impacts.

Given the complex nature of dairy systems and the interrelated social-ecological processes, policies working within paradigms of sustainable intensification and multifunctionality have limited prospects for success. Policies rooted in these frameworks tend to target single dimensions of dairy system impacts, overlooking complex overlaps among the multiple dimensions. For example, sustainable intensification addresses environmental aspects while paying less attention to animal welfare, human health, and rural development (Garnett 2014). Moreover, despite everincreasing specialization in the dairy industry, agricultural policies are often not tailored to the specificities of dairying. We suggest that there is a need for governance mechanisms that can address the unique issues of dairy systems and that are also flexible enough to account for these systems' spatial and temporal variations. The need for proactive policies regulating dairy systems is evidenced by the variations in the environmental impacts of various production models (Poore and Nemecek 2018).

This review on the causes and impacts of dairy intensification highlights a clear and urgent need for systemic transformations. The rapid intensification of dairy production has exacerbated $\mathrm{CO}_{2}$ emissions, animal welfare abuses, inequities in human health, and the eroding of rural 
livelihoods and cultural landscapes. Yet transformation is itself a political process. Policies aiming to influence transformative adaptation within dairy systems should be informed by analysis of power differentials in effort to gauge the equity of agricultural policies (Alston et al. 2017). Recognition that dairy production affects the environment, health, and animal and human welfare in complex and nonlinear ways must come alongside investigation of the politics surrounding how these dimensions are defined and assessed. In other words, what definitions, metrics, units, and scales are employed? Comprehensive studies that consider how these outcomes emerge at the interface of broader structural change (e.g. shifting trade policies) and heterogeneous 'local' social-environmental contexts are especially needed (Galt 2013).

Specifically, research is needed that considers dairy landscapes within broader processes of socioecological change. This work should document the uneven social and environmental outcomes that emerge during dairy system transitions, whether these are transitions to more intensive production or towards more multifunctional or agroecological systems. This focus on social inequalities will help inform transformations to more just food futures. The transitions that have occurred to this point within dairy systems have been scripted by powerful entities, including dairy processors and retailers. This political economy has restricted alternative strategies like agroecology and community-supported agriculture and has rarefied approaches like SI and organic agriculture, by making these palatable to conventional dairy operations. This has meant incremental, site-specific changes rather than systemic changes to the food system that can also address entrenched inequalities. In reviewing the complexities and intersections of multiple elements of dairy system change, this paper may help reimagine more just and sustainable pathways of change in of dairy systems.

Acknowledgements The research informing this article was supported by the Wellcome Trust, Our Planet Our Health (Livestock, Environment and People - LEAP), award number 205212/Z/16/Z. Alexandra Sexton provided helpful feedback on earlier versions of the manuscript, as did two anonymous reviewers. The authors alone bear responsibility for any errors in fact or interpretation.

Open Access This article is distributed under the terms of the Creative Commons Attribution 4.0 International License (http:// creativecommons.org/licenses/by/4.0/), which permits unrestricted use, distribution, and reproduction in any medium, provided you give appropriate credit to the original author(s) and the source, provide a link to the Creative Commons license, and indicate if changes were made.

\section{REFERENCES}

Alexander, D.D., L.C. Bylsma, A.J. Vargas, S.S. Cohen, A. Doucette, M. Mohamed, S.R. Irvin, P.E. Miller, et al. 2016. Dairy consumption and CVD: A systematic review and meta-analysis. British Journal of Nutrition 115: 737-750.

Alkon, A., and T.M. Mares. 2012. Food sovereignty in US food movements: Radical visions and neoliberal constraints. Agriculture and Human Values 29: 347-359.

Allen, P. 2008. Mining for justice in the food system: Perceptions, practices, and possibilities. Agriculture and Human Values 25: $157-161$

Alston, M., J. Clarke, and K. Whittenbury. 2017. Gender relations, livelihood strategies, water policies and structural adjustment in the Australian dairy industry. Sociologia Ruralis 57: 752-768.

Battini, I.F., A. Agostini, V. Tabaglio, and S. Amaducci. 2016. Environmental impacts of different dairy farming systems in the Po Valley. Journal of Cleaner Production 112: 91-102.

Blayney, D.P. 2002. The changing landscape of U.S. milk production. United States Department of Agriculture Statistical Bulletin 978. Washington, DC: USDA.

Bonaudo, T., B.B. Amaury, R. Sabatier, J. Ryschawy, S. Bellon, F. Leger, D. Magda, and M. Tichit. 2014. Agroecological principles for the redesign of integrated crop-livestock systems. European Journal of Agronomy 57: 43-51.

Buller, H.J., and C. Morris. 2003. Farm animal welfare: A new repertoire of nature-society relations or modernism re-embedded? Sociologia Ruralis 43: 216-237.

Burton, R.J.F., S. Peoples, and M.H. Cooper. 2012. Building 'cowshed cultures': A cultural perspective on the promotion of stockmanship and animal welfare on dairy farms. Journal of Rural Studies 28: 174-187.

Cederberg, C., and B. Mattsson. 2000. Life cycle assessment of milk production: A comparison of conventional and organic farming. Journal of Cleaner Production 8: 49-60.

Clark, M., and D. Tilman. 2017. Comparative analysis of environmental impacts of agricultural production systems, agricultural input efficiency, and food choice. Environmental Research Letters 12: 111002.

Dairy UK. 2017. The White Paper 2017. London: Dairy UK. http:// www.dairyuk.org/images/documents/publications/THEWHITE-PAPER-2017.pdf. Accessed 6 July 2018.

Davidson, A. 2002. Globalisation, uneven development, and marginalization: Dairy restructuring in New South Wales. Australian Journal of Social Issues 37: 85-102.

Davidson, A.P., and H.K. Schwarzweller. 1995. Marginality and uneven development: The decline of dairying in Michigan's north country. Sociologia Ruralis 35: 40-66.

Dehghan, M., A. Mente, S. Rangaranjan, P. Sheridan, V. Mohan, R. Iqbal, R. Gupta, S. Lear, et al. 2018. Association of dairy intake with cardiovascular disease and mortality in 21 countries from five continents (PURE): A prospective cohort study. Lancet 392: 2288-2297.

De Lucia, C., P. Pasquale, and V. Vecchione. 2017. The Milk and Dairy Sector in the European Union: Environmental and Policy Issues. Chapter 5.1.1.

Del Prado, A., K. Mas, G. Pardo, and P. Gallejones. 2013. Modelling the interactions between $\mathrm{C}$ and $\mathrm{N}$ farm balances and GHG emissions from confinement dairy farms in northern Spain. Science of the Total Environment 465: 156-165. 
Dibden, J., C. Potter, and C. Cocklin. 2009. Contesting the neoliberal project for agriculture: Productivist and multifunctional trajectories in the European Union and Australia. Journal of Rural Studies 25: 299-308.

Dross, C., K. Prince, F. Jiguet, and M. Tichit. 2017. Contrasting bird communities along production gradients of crops and livestock in French farmlands. Agriculture, Ecosystems \& Environment 253: 55-61.

Dumont, B., E. González-García, M. Thomas, and L. FortunLamothe. 2014. Forty research issues for the redesign of animal production systems in the 21st century. Animal 8: 1382-1393.

Dupuis, E.M. 2002. Nature's perfect food: How milk became America's drink, 312. New York: NYU Press.

Emel, J., and H. Neo (eds.). 2015. Political ecologies of meat, 392. Routledge: New York.

Eshel, G., A. Shepon, T. Makov, and R. Milo. 2014. Land, irrigation water, greenhouse gas, and reactive nitrogen burdens of meat, eggs, and dairy production in the United States. PNAS 111: 11996-12001. https://doi.org/10.1073/pnas.1402183111.

European Commission. 2016. EU Dairy Farms Report Based on 2013 FADN Data. Brussels: European Commission. https://ec.europa. eu/agriculture/fadn/documents/dairy-report-2015_en.pdf. Accessed 6 July 2018.

FAO. 2018a. Dairy and dairy products. In $O E C D-F A O$ agricultural outlook 2018-2027. Rome: Food and Agriculture Organization of the United Nations. http://www.fao.org/docrep/i9166e/ i9166e_Chapter7_Dairy.pdf. Accessed 6 June 2018.

FAO. 2018b. Livestock and agroecology. Rome: Food and Agriculture Organization of the United Nations.

Flaten, O. 2002. Alternative rates of structural change in Norwegian dairy farming: Impacts on costs of production and rural employment. Journal of Rural Studies 18: 429-441.

Foote, K.J., M.K. Joy, and R.G. Death. 2015. New Zealand dairy farming: Milking our environment for all its worth. Environmental Management 56: 709-720.

Foresight. (2011). The future of food and farming. London: Government Office for Science.

Francis, C., G. Lieblein, S. Gliessman, T.A. Breland, N. Creamer, R. Harwood, L. Salomonsson, J. Helenius, D. Rickerl, R. Salvador, M. Wiedenhoeft, S. Simmons, P. Allen, M. Altieri, C. Flora, and R. Poincelot. 2003. Agroecology: The ecology of food systems. Journal of Sustainable Agriculture 22: 99-118.

Fraser, D. 2008. Understanding animal welfare. Acta Veterinaria Scandinavica 50: S1.

Freidberg, S. 2009. Fresh: A perishable history, 408. Cambridge: Harvard University Press.

Galt, R.E. 2013. Placing food systems in first world political ecology: A review and research agenda. Geography Compass 7: 637-658.

Garner, R. (ed.). 2016. Animal rights: The changing debate, 218. London: Palgrave Macmillan.

Garnett, T., M.C. Appleby, A. Balmford, J.J. Bateman, T.G. Benton, P. Bloomer, B. Burlingame, M. Dawkins, et al. 2013. Sustainable intensification in agriculture: Premises and policies. Science 341: 33-34.

Garnett, T. 2011. Where are the best opportunities for reducing greenhouse gas emissions in the food system (including the food chain)? Food Policy 36: 23-32.

Garnett, T. 2014. Three perspectives on sustainable food security: Efficiency, demand restraint, food system transformation. What role for life cycle assessment? Journal of Cleaner Production 73: $10-18$.

Garzon, I. 2005. Multifunctionality of agriculture in the European Union: Is there substance behind the discourse's smoke? Center on Institutions and Governance Presentation Paper No. 20. UC Berkeley.
Gerssen-Gondelach, S.J., R.B.G. Lauwerijssen, P. Havlik, M. Herrero, H. Valin, A.P.C. Faaij, and B. Wicke. 2017. Intensification pathways for beef and dairy cattle production systems: Impacts on GHG emissions, land occupation and land use change. Agriculture, Ecosystems \& Environment 240: 135-147.

Gliessman, S.R. 2007. Agroecology: The ecology of sustainable food systems. Boca Raton: CRC.

Godfray, H.C.J., J.R. Beddington, I.R. Crute, L. Haddad, D. Lawrence, J.F. Muir, J. Pretty, S. Robinson, et al. 2010. Food security: The challenges of feeding 9 billion people. Science 327: 812-818.

Godfray, C.J. 2015. The debate over sustainable intensification. Food Security 7: 199-208.

Godfray, C.J., and T. Garnett. 2014. Food security and sustainable intensification. Philosophical Transactions of the Royal Society $B$ 369: 1-10.

Guthman, J. 2004. Agrarian dreams: The paradox of organic farming in California, 264. Berkeley: University of California Press.

Guthman, J. 2011. Weighing in: Obesity, food justice, and the limits of capitalism, 242. Berkeley: University of California Press.

Haskell, M.J., L.J. Rennie, V.A. Bowell, M.J. Bell, and A.B. Lawrence. 2006. Housing system, milk production and zerograzing effects on lameness and leg injury in dairy cows. Journal of Dairy Science 89: 4259-4266.

Jay, M. 2006. The political economy of a productivist agriculture: New Zealand dairy discourses. Food Policy 32: 266-279.

Jay, M., and M. Morad. 2007. Crying over spilt milk: A critical assessment of the ecological modernization of New Zealand's dairy industry. Society and Natural Resources 20: 469-478.

Jerrentrup, S., S. Klimek, E. Marchiori, G. Bittante, M. Ramanzin, E. Sturaro, and L. Marini. 2016. Impact of dairy farming on butterfly diversity in Alpine summer pastures. Agriculture, Ecosystems \& Environment 232: 38-45.

Koeck, A., S. Loker, F. Miglior, D.F. Kelton, J. Jamrozik, and F.S. Schenkel. 2014. Genetic relationships of clinical mastitis, cystic ovaries, and lameness with milk yield and somatic cell score in first-lactation Canadian Holsteins. Journal of Dairy Science 97: $5806-5813$.

Krieg, E.J. 2014. The social and environmental costs of milk production: Trends and resistance in Vermont. The American Journal of Economics and Sociology 73: 210-236.

Lebacq, T., P.V. Baret, and D. Stilmant. 2015. Role of input selfsufficiency in the economic and environmental sustainability of specialised dairy farms. Animal 9: 544-552.

LeBlanc, S.J., K.D. Lissemore, D.F. Kelton, T.F. Duffield, and K.E. Leslie. 2006. Major advances in disease prevention in dairy cattle. Journal of Dairy Science 89: 1267-1289.

Loos, J., D.J. Abson, M.J. Chappell, J. Hanspach, F. Mikulcak, M. Tichit, and J. Fischer. 2014. Putting meaning back into "sustainable intensification". Frontiers in Ecology and the Environment 12: 356-361.

Lovell, S.T., S. De Santis, C.A. Nathan, M. Breton Olson, V.E. Méndez, H.C. Kominami, D.L. Erickson, K.S. Morris, et al. 2010. Integrating agroecology and landscape multifunctionality in Vermont: An evolving framework to evaluate the design of agroecosystems. Agricultural Systems 103: 327-341.

Marsden, T., and R. Sonnino. 2008. Rural development and the regional state: Denying multifunctional agriculture in the UK. Journal of Rural Studies 24: 422-431.

Martin, G., and M. Willaume. 2016. A diachronic study of greenhouse gas emissions of French dairy farms according to adaptation pathways. Agriculture, Ecosystems \& Environment 221: 50-59.

McCarthy, J. 2005. Rural geography: Multifunctional rural geographies - reactionary or radical? Progress in Human Geography 29: $773-782$. 
McGregor, A., and D. Houston. 2017. Cattle in the Anthropocene: Four propositions. Transactions of the Institute of British Geographers 43: 3-16.

Moraine, M., M. Duru, P. Nicholas, P. Leterme, and O. Therond. 2014. Farming system design for innovative crop-livestock integration in Europe. Animal 8: 1204-1217.

Neo, H., and J. Emel. 2017. Geographies of meat: Politics, economy and culture, 280. New York: Routledge.

O'Brien, D., J.L. Capper, P.C. Garnsworthy, C. Grainger, and L. Shalloo. 2014. A case study of the carbon footprint of milk from high-performing confinement and grass-based dairy farms. Journal of Dairy Science 97: 1835-1851.

O’Brien, D., T. Hennessy, B. Moran, and L. Shalloo. 2015. Relating the carbon footprint of milk from Irish dairy farms to economic performance. Journal of Dairy Science 98: 7394-7407.

Ohl, F., and F.J. Van der Staay. 2012. Animal welfare: At the interface between science and society. The Veterinary Journal 192: 13-19.

Oltenacu, P.A., and D.M. Broom. 2010. The impact of genetic selection for increased milk yield on the welfare of dairy cows. Animal Welfare 19: 39-49.

Poore, J., and T. Nemecek. 2018. Reducing food's environmental impacts through producers and consumers. Science 360: 987-992.

Pretty, J., C. Toulmin, and S. Williams. 2011. Sustainable intensification in African agriculture. International Journal of Agricultural Sustainability 9: 5-24.

Pretty, J.N., et al. 2000. An assessment of the total external costs of UK agriculture. Agricultural Systems 65: 113-136.

Rache, M., and N. Argent. 2015. The fall and rise of agricultural productivism? An Antipodean viewpoint. Progress in Human Geography 39: 621-635.

Ricard, D. 2015. Dairy cooperatives in the French mountains. Journal of Alpine Research 103: 1-13.

Salou, T., H.M.G. van der Werf, F. Vevert, A. Forslund, J. Hercule, and C. Le Mouel. 2017. Could EU dairy quota removal favour some dairy production systems over others? The case of French dairy production systems. Agricultural Systems 153: 1-10.

Scarsbrook, M.R., and A.R. Melland. 2015. Dairying and waterquality issues in Australia and New Zealand. Animal Production Science 55: 856-868.

Shields, S., and G. Orme-Evans. 2015. The impacts of climate change mitigation strategies on animal welfare. Animals 5: 361-394.

Soteriades, A.D., A.W. Stott, S. Moreau, T. Charroin, M. Blanchard, J. Liu, and P. Faverdin. 2016. The relationship of dairy farm ecoefficiency with intensification and self-sufficiency. PLOS ONE 11: e0166445.

Springmann, M., H.C.J. Godfray, M. Rayner, and P. Scarborough. 2016. Analysis and valuation of the health and climate change cobenefits of dietary change. Proceedings of the National Academy of Sciences of the USA 113: 4146-4151.

Statistics New Zealand. 2012. Infoshare. Statistics New Zealand. http://www.stats.govt.nz/infoshare/.

Tilman, D., and M. Clark. 2014. Global diets link environmental sustainability and human health. Nature 515: 518-522.

Tilman, D., B. Christian, J. Hill, and B.L. Befort. 2011. Global food demand and the sustainable intensification of agriculture. Proceedings of the National Academy of Sciences of the USA 108: 20260-20264.

Tittonell, P. 2014. Ecological intensification of agriculture: Sustainable by nature. Current Opinion in Environmental Sustainability 8: 53-61.

Tomich, T.P., S. Brodt, H. Ferris, R. Galt, W.R. Horwath, E. Kebreab, J.H.J. Leveau, Liptzin, et al. 2011. Agroecology: A review from a global-change perspective. Annual Review of Environment and Resources 36: 193-222.

USDA. 2018. NASS Milk Production (February 2018) https://release. nass.usda.gov/reports/mkpr.

Vandermeer, J., and I. Perfecto. 2017. Ecological complexity and agroecology, 272. London: Routledge.

Vanlauwe, B., D. Coyne, J. Gockowski, S. Hauser, J. Huising, C. Masso, G. Nziguheba, Schut, et al. 2014. Sustainable intensification and the African smallholder farmer. Current Opinion in Environmental Sustainability 8: 15-22.

Vanloqueren, P., and V. Baret. 2009. How agricultural research systems shape a technological regime that develops genetic engineering but locks out agroecological innovations. Research Policy 38: 971-983.

von Keyserlingk, M.A.G., J. Rushen, A.M. de Passillé, and D.M. Weary. 2009. Invited review: The welfare of dairy cattle: Key concepts and the role of science. Journal of Dairy Science 92: 4101-4111.

von Keyserlingk, M.A.G., and D.M. Weary. 2017. A 100-year review: Animal welfare in the Journal of Dairy Science-The first 100 years. Journal of Dairy Science 100: 10432-10444.

Webster, J. 1994. Animal welfare: A cool eye towards Eden, 284. Oxford: Blackwell Science.

Westhoek, H.J.P., T. Lesschen, S. Rood, A.De Wagner, D. Marco, A. Murphy-Bokern, H.Grinsven Leip, et al. 2014. Food choices, health and environment: Effects of cutting Europe's meat and dairy intake. Global Environmental Change 26: 196-205.

Wezel, A., and V. Soldat. 2009. A quantitative and qualitative historical analysis of the scientific discipline of agroecology. International Journal of Agricultural Sustainability 7: 3-18.

World Health Organization (WHO). 1946. Constitution of the World Health Organization as adopted by the International Health Conference, New York.

World Health Organization (WHO). 2018. The state of food security and nutrition in the world. Geneva.

Wibbelmann, M., U. Schmutz, J. Wright, D. Udall, F. Rayns, M. Kneafsey, L. Trenchard, J. Bennett, and M. Lennartsson. 2013. Mainstreaming agroecology: Implications for global food and farming systems. Centre for Agroecology and Food Security discussion paper. Coventry: Centre for Agroecology and Food Security.

Wilson, G. 2007. Multifunctional agriculture: A transition theory perspective, 386. Oxford: CABI.

Wilson, G. 2008. From 'weak' to 'strong' multifunctionality: Conceptualising farm-level multifunctional transitional pathways. Journal of Rural Studies 24: 367-383.

Wilson, G.A., and R.J.F. Burton. 2015. 'Neo-productivist' agriculture: Spatio-temporal versus structuralist perspectives. Journal of Rural Studies 38: 52-64.

Wing, S., and S. Wolf. 2000. Intensive livestock operations, health, and quality of life among eastern North Carolina residents. Environmental Health Perspectives 108: 233-238.

Zimmermann, A., and T. Heckelei. 2012. Structural change of European dairy farms: A cross-regional analysis. Journal of Agricultural Economics 63: 576-603.

Publisher's Note Springer Nature remains neutral with regard to jurisdictional claims in published maps and institutional affiliations.

\section{AUTHOR BIOGRAPHIES}

Nathan Clay $(\square)$ is a postdoctoral researcher at the University of Oxford in the School of Geography and the Environment and the Oxford Martin Programme on the Future of Food. His research 
considers the human-environment dimensions of food and agriculture amid global climate change.

Address: School of Geography and the Environment, University of Oxford, South Parks Road, Oxford OX1 3QY, UK.

e-mail: nathan.clay@zoo.ox.ac.uk

Tara Garnett runs the Food Climate Research Network at the University of Oxfords. She has a particular interest in the debates around livestock and their role in sustainable food systems.

Address: Food Climate Research Network, Environmental Change
Institute, University of Oxford, South Parks Road, Oxford OX1 3QY, UK.

e-mail: taragarnett@fcrn.org.uk

Jamie Lorimer is an Associate Professor in the School of Geography and the Environment at the University of Oxford. His research explores the social dimensions of environmental management.

Address: School of Geography and the Environment, University of Oxford, South Parks Road, Oxford OX1 3QY, UK.

e-mail: jamie.lorimer@ouce.ox.ac.uk 